\title{
Heparin-induced hepatotoxicity
}

\author{
Khalid A AL-Mekhaizeem MD FRCPC, Averell H Sherker MD FRCPC
}

KA AL-Mekhaizeem, AH Sherker. Heparin-induced hepatotoxicity. Can J Gastroenterol 2001;15(8):527-530. Heparininduced hepatotoxicity is well described in the literature, but rarely recognized clinically. Two cases were recently encountered. In the first case, elevated aminotransferase levels occurred after four days of heparin therapy. In the second case, enzyme levels increased after only $8 \mathrm{~h}$ of heparin treatment. To the authors' knowledge, this short time interval between the administration of heparin and liver enzyme elevations has not been described. The objective of this report is to increase the clinical awareness of this interesting and under-recognized biochemical observation.

Key Words: Alanine aminotransferase; Aspartate aminotransferase; Heparin; Hepatotoxicity; Lactate dehydrogenase; Liver enzymes

\section{Hépatotoxicité causée par l'héparine}

RÉSUMÉ : L'hépatotoxicité causée par l'héparine est bien décrite dans la littérature, mais elle est rarement reconnue sur le plan clinique. Deux cas ont récemment été recensés. Dans le premier cas, les taux élevés d'aminotransférase sont survenus après quatre jours de traitement à l'héparine. Dans le second cas, les taux d'enzyme ont augmenté après huit heures seulement de traitement à l'héparine. À notre connaissance, ce bref intervalle entre l'administration de l'héparine et les élévations des enzymes hépatiques n'a encore jamais été décrit. L'objectif de ce rapport est de sensibiliser les lecteurs à ce phénomène biochimique intéressant et trop peu souvent reconnu.
$\mathrm{H}$ eparin is commonly prescribed for the prevention and treatment of thromboembolic disorders and acute coronary syndromes (1). The well recognized side effects of heparin therapy include bleeding, thrombocytopenia, alopecia and osteoporosis (1).

While heparin-induced hypertransaminasemia has been found to occur in up to $90 \%$ of treated patients (2), its clinical manifestations are under-recognized. Typically, liver transaminase and lactate dehydrogenase levels rise five to 10 days after starting heparin treatment and usually return to normal despite continuation of therapy (2). Although there is marked enzyme elevations, hepatic dysfunction has not been described. Furthermore, the underlying condition being treated does not appear to be a determinant of heparin-induced hepatotoxicity. The mechanism of liver injury is unclear. This interesting biochemical observation has been described following both standard dose intravenous therapy and low dose subcutaneous prophylactic therapy.

Two cases of elevated liver enzymes without clinical evidence of liver dysfunction following intravenous heparin therapy are reported. This case report and review of the literature suggest that a greater recognition of the benign and reversible nature of heparin-induced liver enzyme elevation should preclude aggressive diagnostic work-up in most instances.

\section{CASE PRESENTATIONS}

Patient 1: An 83-year-old man presented to the emergency room at the authors' institution with crescendo-pattern, unstable angina of three days' duration. His past medical history was unremarkable, and he was not taking any med-

Division of Gastroenterology, Sir Mortimer B Davis Jewish General Hospital, McGill University, Montreal, Quebec

Correspondence: Dr Averell H Sherker, Sir Mortimer B Davis Jewish General Hospital, 3755, chemin de la Côte-Ste-Catherine, Montréal,

Québec, H3T 1E2. Telephone 514-340-8223, fax 514-340-8101, e-mail asherker@gas.jgh.mcgill.ca

Received for publication June 14, 2000. Accepted October 26, 2000 


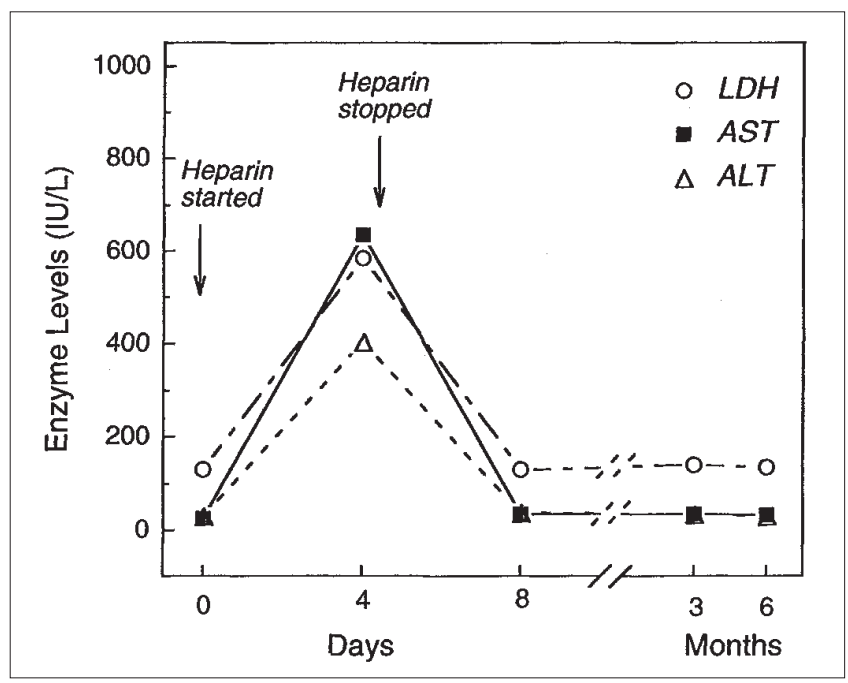

Figure 1) Serum liver enzyme levels for patient 1 before the administration of heparin (day 0) and after four days of heparin treatment. Heparin administration was terminated on day 4 , and the serum liver enzyme levels were measured on day 8 , and again three and six months later. ALT Alanine aminotransferase; AST Aspartate aminotransferase; LDH Lactate dehydrogenase

ications. He denied alcohol consumption and did not smoke. Review of systems was unremarkable, and there were no risk factors for chronic liver disease.

Clinical examination revealed an elderly man in no apparent distress. There was no evidence of pallor or jaundice and no stigmata of chronic liver disease. Vital signs revealed a blood pressure of $130 / 80 \mathrm{mmHg}$, a regular pulse rate of 88 beats/min, a respiratory rate of 22 breaths $/ \mathrm{min}$ and a body core temperature of $37^{\circ} \mathrm{C}$. Cardiac examination revealed normal heart sounds with no added sounds and the jugular venous pressure was not elevated. Examination of the chest revealed normal breath sounds with no adventitious sounds. Abdominal examination showed no evidence of hepatosplenomegaly. The remainder of the physical examination results were within normal limits.

Baseline investigation included normal complete blood counts, cardiac enzymes and normal liver profile. The chest $\mathrm{x}$-ray was normal with no evidence of heart failure. The electrocardiogram (ECG) showed ST-T changes compatible with recent ischemia in the anterolateral leads. The patient was diagnosed with acute coronary syndrome, without any evidence of acute myocardial infarction or heart failure, and was admitted to the coronary care unit. Heparin sodium (porcine) was administered by continuous intravenous infusion (bolus dose, $5000 \mathrm{U}$; maintenance dose, $32,000 \mathrm{U}$ per $24 \mathrm{~h}$ ) over five days, in addition to oral acetylsalicylic acid and fosinopril.

His hospital course was uncomplicated with no recurrence of the retrosternal chest pain. On the fourth hospital day, a routine blood test revealed a significant elevation of liver enzyme levels: aspartate aminotransferase $635 \mathrm{IU} / \mathrm{L}$ (normal 10 to $37 \mathrm{IU} / \mathrm{L}$ ); alanine aminotransferase $405 \mathrm{IU} / \mathrm{L}$ (normal 10 to $40 \mathrm{IU} / \mathrm{L}$ ); and lactate dehydrogenase $585 \mathrm{U} / \mathrm{L}$ (normal 122 to $220 \mathrm{IU} / \mathrm{L}$ ) (Figure 1). Other laboratory investigations found complete blood counts to be normal and the coagulation profile to be in the therapeutic range. Heparin sodium was discontinued on day 5 , and on day 8 the liver enzymes returned to near normal levels (Figure 1). An outpatient work-up was performed after discharge. Viral hepatitis serology (A, B and C) and autoimmune markers were negative, and iron studies were normal. Liver enzymes remained normal three and six months later (Figure 1).

Patient 2: An 80-year-old woman presented to the emergency room with a sudden onset of right-sided chest pain. Her past medical history was unremarkable and she was not taking any medication. She was a nonsmoker and denied alcohol intake. She also denied previous similar episodes. Three hours before her visit, she developed a sudden rightsided chest pain while she was at rest. The pain was severe, worsened with breathing, did not radiate and lasted for about $30 \mathrm{~min}$. The pain was associated with mild shortness of breath. There was no history of hemoptysis, palpitation or syncope. In addition, there was no history of swelling of the legs, prolonged immobilization or recent surgery. Review of systems was unremarkable, and there were no risk factors for chronic liver disease.

On examination, she was an elderly lady in moderate distress, complaining of chest pain. There was no evidence of pallor, jaundice or stigmata of chronic liver disease. Vital signs showed a blood pressure of $130 / 90 \mathrm{mmHg}$, a pulse rate of 90 beats/min, a respiratory rate of 35 breaths $/ \mathrm{min}$ and a body core temperature of $37^{\circ} \mathrm{C}$. At no time was she hypotensive. Cardiovascular examination was normal, and jugular venous pressure was not elevated. Chest examination was normal. The remainder of the clinical examination results were within normal limits.

Investigation included normal complete blood counts, cardiac enzymes and liver profile. Imaging studies included a normal chest $\mathrm{x}$-ray. The ECG showed sinus tachycardia without any ST-T changes. Acute pulmonary embolism was suspected on clinical grounds, and heparin sodium (porcine) was initiated by a continuous intravenous infusion (bolus dose $5000 \mathrm{U}$; maintenance dose 32,000 U per $24 \mathrm{~h})$.

Complete blood counts, coagulation profile and liver enzyme profile were performed after $8 \mathrm{~h}$ of heparin treatment. The blood work confirmed significant elevation of liver enzyme levels: aspartate aminotransferase $881 \mathrm{IU} / \mathrm{L}$ (normal 10 to $37 \mathrm{IU} / \mathrm{L}$ ); alanine aminotransferase $762 \mathrm{IU} / \mathrm{L}$ (normal 10 to $40 \mathrm{IU} / \mathrm{L}$ ); and lactate dehydrogenase $958 \mathrm{IU} / \mathrm{L}$ (normal 122 to $220 \mathrm{IU} / \mathrm{L}$ ) (Figure 2). Other laboratory investigations including complete blood counts were normal and the partial thromboplastin time was in the therapeutic range. Further investigation included a lung ventilation-perfusion scan that was interpreted as an intermediate probability for pulmonary embolism. A pulmonary angiogram was normal and effectively excluded a pulmonary embolism. Heparin was discontinued. Four hours later, liver enzyme levels returned to their preheparin baseline levels (Figure 2). Liver enzyme levels were normal at 
follow-up visits to the clinic three and six months later (Figure 2). Viral hepatitis serology (A, B and C) and autoimmune antibodies were negative, and iron studies were normal.

\section{DISCUSSION}

Liver enzyme derangement has been reported in patients receiving heparin therapy (3-9). This phenomenon results in isolated biochemical liver enzyme changes without overt liver disease. The mechanisms underlying these transaminase elevations are unknown, but it is postulated that heparin induces the release of glyceride lipase, which appears to interfere with mitochondrial cell membrane integrity, causing an increase of transaminases in the circulation (10). Although early reports $(11,12)$ proposed that heparin-induced hepatotoxicity may be dose-dependant, a subsequent prospective randomized trial showed that this was not the case (7). A report from Saffle and associates (3) showed a greater incidence of significant elevation in serum transaminase levels in subjects receiving porcine heparin (93\%) than in those receiving bovine heparin (37\%). A follow-up randomized, controlled trial by Dukes et al (7) failed to confirm this difference. This phenomenon has also been described in patients receiving low molecular weight heparin (13). The liver enzyme pattern in the majority of the reported cases is of an isolated transaminasemia, although a cholestatic picture has been reported in three cases (14).

The two present cases illustrate probable heparin-related transient increases in liver transaminase levels. Neither of these patients exhibited hypersensitivity-type symptoms, thrombocytopenia or other recognized adverse effects of heparin therapy. The first case is more typical of the pattern of liver enzyme elevations described in the literature, where abnormalities are detected after a latent period of three to four days of heparin therapy (Figure 1). Patient 1 had a 10to 20 -fold increase in the level of aminotransferase, and a two- to threefold increase in the level of lactate dehydrogenase four days after starting heparin treatment. The magnitude of these liver enzyme elevations is higher than the typically reported three- to fivefold rise in aminotransferase levels (1). The absence of any immunoallergic signs, including fever, rash, arthralgia and mylagia in patient 1 further suggests that the increase in liver enzymes is a direct heparin effect and not the result of serum-like sickness. The absence of congestive heart failure and other risk factors for acute and chronic liver disease, together with the fact that enzyme levels remained normal three and six months later despite continued use of his other medications, suggests that the cause of this transient liver enzyme elevation was heparin.

The second case is an atypical example of heparininduced hepatotoxicity. Liver enzyme elevations occurred after only $8 \mathrm{~h}$ of heparin treatment compared with the three to four days reported in the literature (2) (Figure 2). This very short time interval between the administration of heparin and the liver enzyme increases had not previously

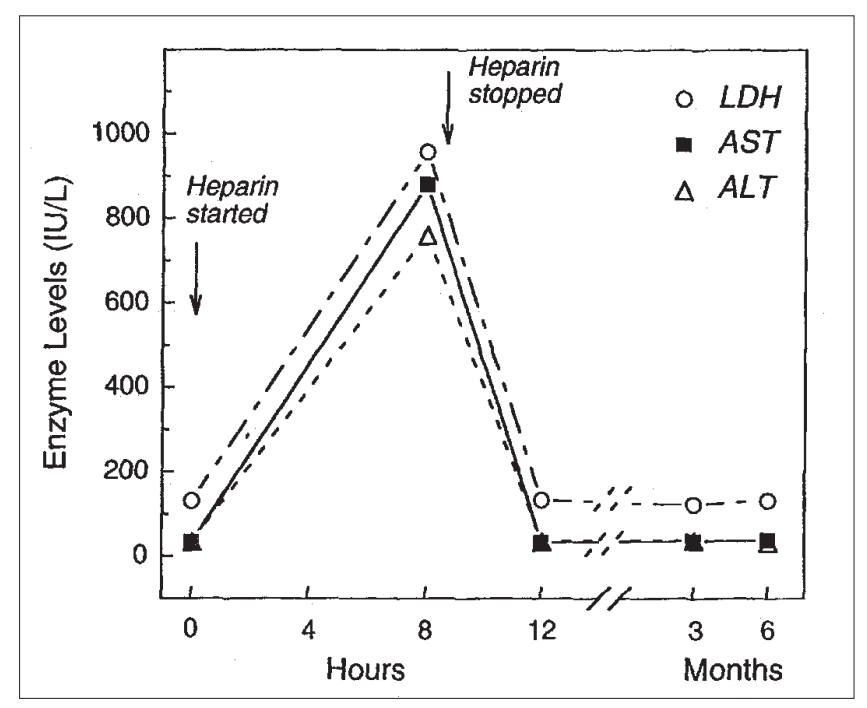

Figure 2) Serum liver enzyme levels for patient 2 before the administration of heparin (hour 0 ) and after $8 \mathrm{~h}$ of heparin treatment. Heparin administration was terminated on hour 8 , and the serum liver enzyme levels were measured on hour 12, and again three and six months later. ALT Alanine aminotransferase; AST Aspartate aminotransferase; LDH Lactate dehydrogenase

been reported. In addition, at this $8 \mathrm{~h}$ time point, the magnitude of the liver enzyme enhancements, 20 - to 30 -fold in the level of aminotransferases and four- to fivefold in the lactate dehydrogenase level, is much greater than typically reported (1). Once again, the absence of other hepatotoxic medications, congestive heart failure, risk factors for acute and chronic liver disease, as well as the rapid and persistent decrease of the liver enzymes levels $12 \mathrm{~h}$, and three and six months later, argue in favour of a heparin effect.

\section{CONCLUSIONS}

These case reports underscore several important points. The common occurrence of heparin-induced hepatotoxicity should be appreciated to prevent unnecessary and possibly invasive investigations such as liver biopsy. Although the magnitude of the enzyme elevations may be very high, acute or chronic liver dysfunction has not been reported. If continuation of heparin is indicated, despite liver enzyme elevation, it is unlikely to be associated with clinical sequelae.

\section{REFERENCES}

1. Freedman MD. Pharmacodynamics, clinical indications, and adverse effects of heparin. J Clin Pharmacol 1992;32:584-96.

2. Stricker BHCH. Drug-induced hepatic injury, 2nd ed. In: Dukes MNG, ed. Drug-Induced Disorders, vol 5. New York: Elsevier, 1992:339-40.

3. Saffle JR, Russo J, Dukes GE, Warden OD. The effects of low dose heparin therapy on serum platelet and transaminase levels. J Surg Res 1980;28:297-305.

4. Guevara A, Labarca J, Gonzalez-Martin G. Heparin-induced transaminase elevations: A prospective study. Int J Clin Pharmacol Ther Toxicol 1993;31:137-41.

5. Tison T, Dazzi F, Vianello F, Radossi P, Girolami A. Marked but transitory elevation of hepatic transaminases after subcutaneous calcium heparin adminstration. Acta Haematol 1994;92:54.

6. Toulemonde F, Kher A. Heparins and transaminases: An enigma without importance in 1994. Therapie 1994;49:356-8. 
7. Dukes GE Jr, Sanders SW, Russo J Jr, et al. Trasaminase elevation in patients receiving bovine or porcine heparin. Ann Intern Med 1984;100:646-50.

8. Shlo S, Abraham AS, Breuer R, Sonnenblick M.

Hypertransaminasemia with subcutaneous heparin therapy. Isr J Med Sci 1981;17:1133-5.

9. Sonnenblick M, Oren A, Jacobsonn W. Hyper-transaminasemia with heparin therapy. Br Med J 1975;3:77.

10. Olivecrona I, Herella O, Egelurd T. Lipoprotein lipase in heparin structure, function and clinical implication. New York: Plenum Press, 1975:269-79.
11. Minar E, Ehringer H, Hirschl M, et al. Transaminase increase: A largely unknown side-effect of heparin treatment. Dtsch Med Wochenschr 1980;105:1713-7.

12. Olsson R, Korsan-Bengtsen BM, Korsan-Bengtsen K, Lennartsson J, Waldenstrom J. Serum aminotransferase after low-dose heparin treatment. Acta Med Scand 1978;204:229-30.

13. Christiansen HM, Lassen MR, Borris LC, et al. Biologic tolerance of two different low molecular weight heparins. Semin Thromb Hemost 1991;17:450-4.

14. Olsson R, Leonhardt T. Cholestatic liver reaction during heparin therapy. J Intern Med 1991;229:471-3. 


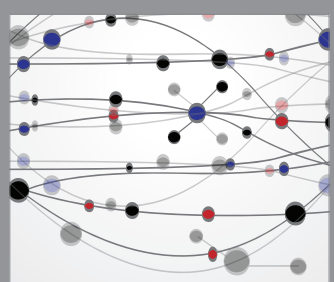

The Scientific World Journal
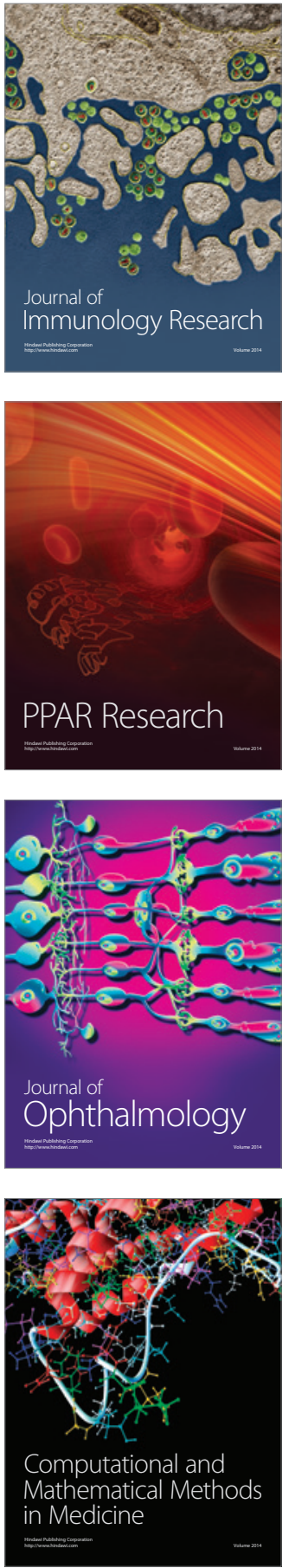

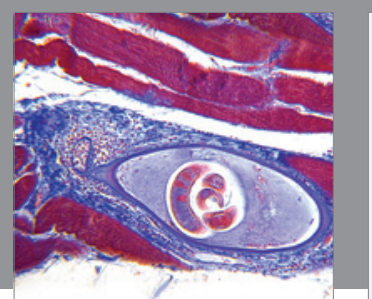

Gastroenterology Research and Practice

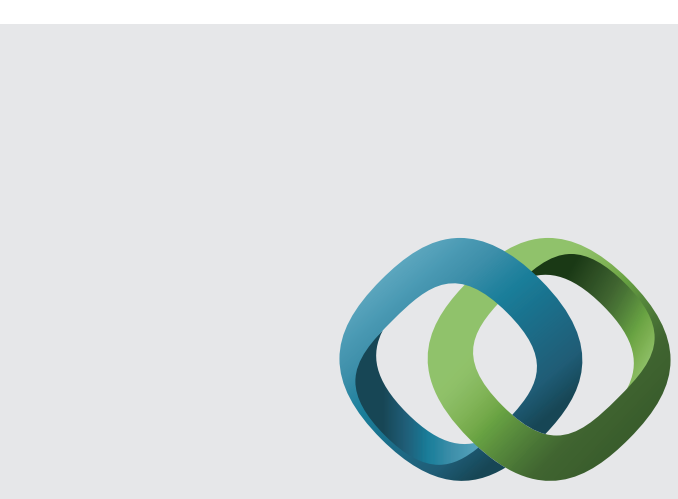

\section{Hindawi}

Submit your manuscripts at

http://www.hindawi.com
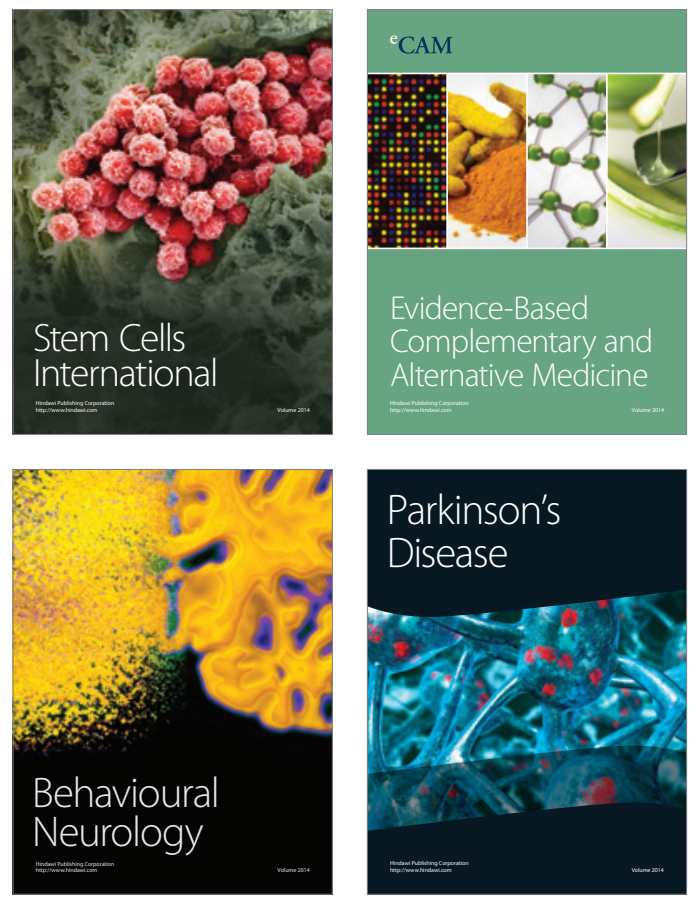
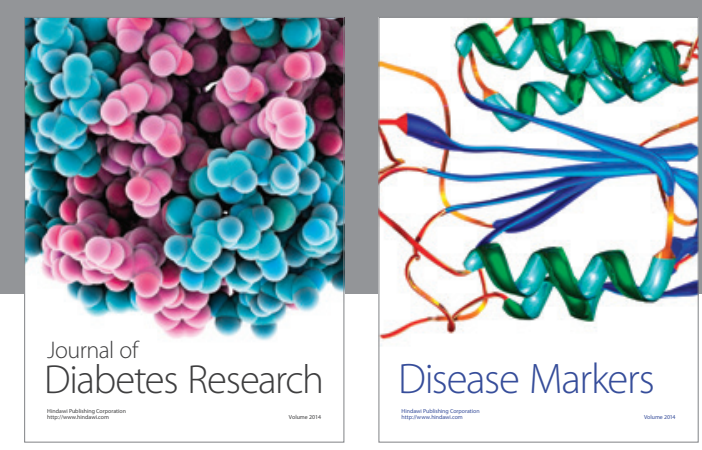

Disease Markers
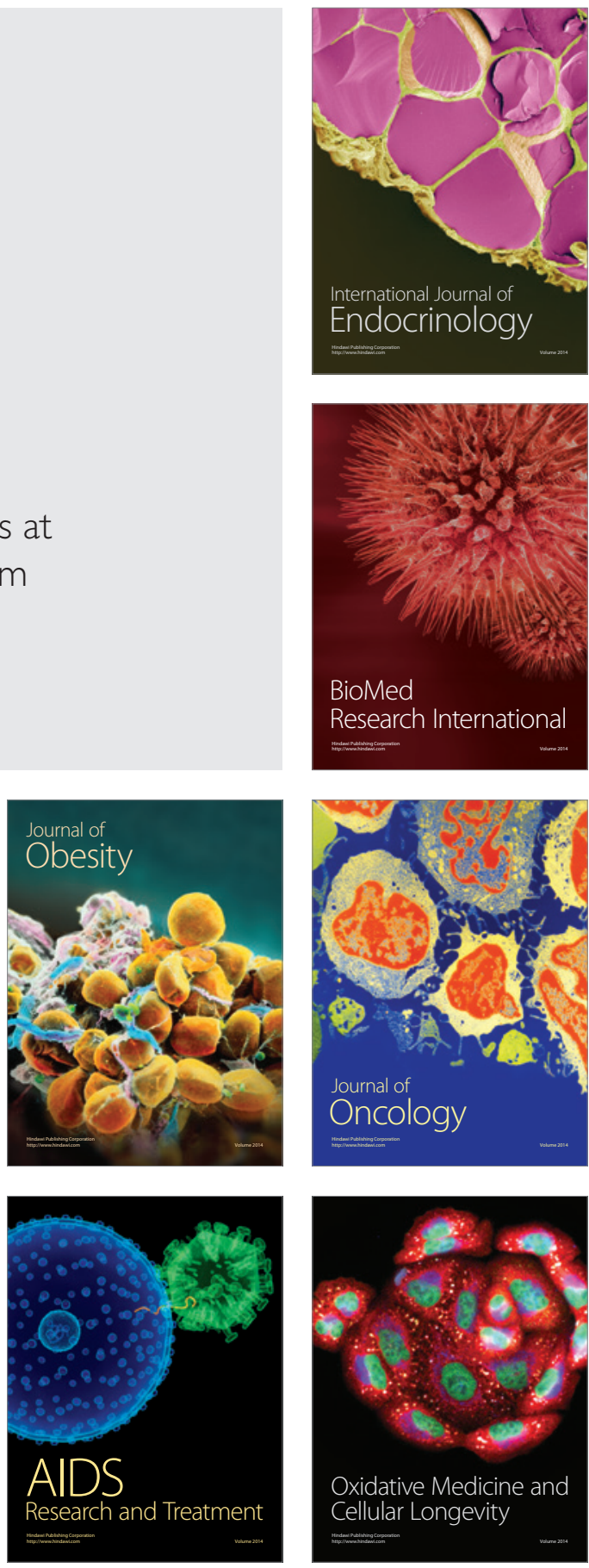